\title{
Measuring government duration and stability in Central Eastern European democracies
}

\author{
COURTENAY RYALS CONRAD \& SONA N. GOLDER \\ Department of Political Science, Florida State University, Tallahassee, FL, USA
}

\begin{abstract}
Existing studies of government duration in parliamentary democracies typically measure the length of a government's tenure in office without accounting for delays in the government formation process. By assuming that a cabinet leaves office on the day prior to the new cabinet taking office, these measures ignore periods during which a government has lost its mandate but is still legally in power as a caretaker government. A consequence is that governments that are actually stable and governments that only appear stable because replacement governments take a long time to form are observationally equivalent. This suggests that some existing studies of government stability are potentially flawed. It also means that a number of interesting research questions cannot be answered with existing data. Many of these questions address the various consequences of caretaker governments. The answers to these questions are relevant for scholars interested in representation and accountability. This article presents a new dataset collected on government duration in eleven Central Eastern European democracies from 1990 to 2008 that specifically takes account of caretaker periods and delays in the government formation process. These data will provide scholars with more flexibility to choose the measure that best reflects their underlying conception of government stability.
\end{abstract}

\section{Introduction}

The publication of Müller-Rommel et al.'s (2004) dataset on eleven Central Eastern European governments was important not only for scholars of the new democracies in this region, but for scholars of parliamentary governments more generally. It added a fresh set of observations for testing implications from theories about government formation and duration. Previously, these hypotheses had been tested on data drawn mainly from Western Europe. Since theories of government formation and duration are typically developed by scholars with detailed knowledge of Western European governments, the opportunity for testing these hypotheses on an entirely new set of countries was particularly welcome (Druckman \& Roberts 2005; Somer-Topcu \& Williams 2008).

To facilitate these kinds of analyses, Müller-Rommel, Fettelschoss \& Harfst's (MRFH) data are organised in the same manner as one of the stan- 
dard data sources for parliamentary government information in Western Europe created by Woldendorp et al. (1998). The authors deliberately chose to organise the data using this structure, arguing that the decision 'makes it possible to analyse the characteristics of government formation, duration and termination. Furthermore, research on the type of coalition and the ideological composition of governments can be conducted for each country, as well as among Central Eastern European countries and between those countries and Western Europe' (Müller-Rommel et al. 2004: 869).

Although an important contribution, we argue that MRFH's measure of the length of government tenure is not necessarily appropriate for all studies of 'the characteristics of government formation, duration and termination' because it does not account for delays in the parliamentary government formation process. Instead, it assumes that the date on which any cabinet leaves office is exactly the day prior to the date on which the new cabinet is installed. For example, Slovakia held legislative elections on 1 October 1994. Vladimir Meciar's government entered office on 13 December - nearly two and a half months after the election. This delay in forming a new government and the existence of an unofficial caretaker government (the outgoing incumbent cabinet under Jozef Moravcik) is not obvious in the MRFH dataset because the authors code the end date of the Moravcik Government as 12 December - the day before Meciar took over as prime minister. Depending on the precise question a researcher is trying to answer, this coding rule - assuming that cabinets continue governing exactly as before, regardless of elections or resignations, until the new government is ready to take over - could pose important difficulties.

More specifically, this approach overlooks caretaker periods in which a government has lost its mandate but remains in office until a new government replaces it. Thus MRFH's coding rule treats cases in which governments appear stable because they really are stable and cases in which governments appear stable only because replacement governments take a long time to form as observationally equivalent. Yet when governments take a long time to form following elections, or when governments collapse prematurely, some government - albeit one without a proper mandate - remains in office. We know surprisingly little about the consequences of these caretaker governments, not because they are theoretically uninteresting, but because most datasets largely ignore them. For instance, in what ways do such governments behave differently than governments that begin life with a mandate? To what extent does this vary across countries, and do institutional rules affect this variation? The answers to these questions are relevant for scholars interested in representation and accountability. Additionally, if government duration is more appropriately measured as the period during which the government has a proper mandate to 
govern, then this has potentially serious consequences for studies examining factors influencing government stability or the consequences of government stability; some of the inferences from these studies may be misleading.

In this article we present new data collected on government duration in eleven Central Eastern European countries from 1990 through 2008. We have tried to follow MRFH (Müller-Rommel et al. 2004) where possible so that the main difference between our datasets, aside from updating the data for the period from 2004-2008, is in the coding rules for the dates on which governments end. Our data specifically take account of caretaker periods following government resignation and delays in the government formation process that are largely ignored in most studies of parliamentary governments.

We begin by providing a description of the variables included in our dataset and the sources we used to collect our data. We then show that government stability depends on the measure used and discuss several different ways to measure government stability. Our objective in this article is to point out that measurement decisions about government duration matter. Consequently, scholars should think carefully about how they wish to conceptualise government duration or stability and take care to match their concepts with the most appropriate measure (Adcock \& Collier 2001). ${ }^{1}$ We also highlight some important open questions that cannot be analysed with existing data but that can be studied with the new dataset presented here.

\section{Measurement and operationalisation}

In accordance with MRFH, we collected our data on Central Eastern European cabinets primarily using Keesings World News Archive (formerly Keesing's Contemporary Archives Record of World Events) as well as country reports from the European Journal of Political Research. ${ }^{2}$ A wide variety of print and internet sources were used to confirm the Keesings and EJPR data. ${ }^{3}$ Data were collected on eleven Central Eastern European countries from their transitions to democracy around 1990 through the end of December 2008: Bulgaria, Croatia, Czech Republic, Estonia, Hungary, Latvia, Lithuania, Poland, Romania, Slovakia and Slovenia. Although we employ a longer time frame, these are the same countries as those in the MRFH data. ${ }^{4}$

Determining the founding date of the new parliamentary democracies in Central Eastern Europe is fraught with difficulties. Full transitions to democracy often take place over long periods of time, making determination of the founding democratic government problematic. To maximise the comparability of our datasets, we follow MRFH in defining a country's founding government as being determined largely by national sovereignty; it is typically the first 
government formed after elections in a politically independent state. This definition applies to Croatia, Estonia, Hungary, Latvia, Lithuania, Poland and Slovenia. In the case of the Czech Republic and Slovakia, the founding government is considered to be the first government following elections after the collapse of the (politically independent) Czechoslovakia. Finally, the founding governments of Bulgaria and Romania are coded as those governments that formed after the start of free elections and various constitutional revisions that had to be approved by constituent assemblies. ${ }^{5}$

Although we use the same basic definition of what constitutes a government as MRFH, it is not always obvious what date marks either the beginning point or the ending point of a particular government as we move from the definition of a government to specific coding rules. For example, does the government begin when an election is held, when a coalition agreement is initially announced, when the government enters office, or when an investiture vote passes? Does a government end when a resignation is first announced or when it is accepted? Or does a government end only when the new government takes office? Consequently, it is important to explicate our coding rules about the dates on which a government begins and ends.

Our data are arranged by individual government, where, following MRFH, a government is defined as having the same prime minister serving in office, the same party composition and the same legislative period (uninterrupted by elections) (Budge \& Keman 1990). Since we are particularly interested in the duration of each government, we first need to know each government's Begin date: the date on which a new government takes office. Although this might seem like easy information to collect, a closer examination reveals that some decisions have to be made by the analyst. For instance, imagine the following scenario. Parliamentary elections are held on 15 June. On 2 July, an announcement of a coalition agreement between three parties is made. On 27 July, a prime minister takes office, and two days later, on 29 July, the full cabinet takes office. Finally, the government passes an investiture vote on 13 August. Which date is the most appropriate for the beginning of the new government? The answer is not immediately obvious. We have chosen to consider the start date of a government as the day on which the full cabinet takes office, rather than the day on which the prime minister alone takes office (if different from that of the full cabinet) or the date on which the government passes an investiture vote (if one is required). In the scenario just presented, we would have coded the Begin date as 29 July, when the complete cabinet takes office. The way we code the beginnings of governments seems to be the same as the approach taken by MRFH. ${ }^{6}$

Similarly strict coding rules were applied to the date of termination of a government. The date on which there is a change in the party composition of 
a government, a change of prime minister or a legislative election would count as the End date for that government. Thus in the scenario presented above, if the previous government were in office up until the election, its End date would have been coded as 15 June when legislative elections were held. ${ }^{7}$ Cabinets also end when their party composition changes. Imagine further that the three-party government that takes office on 29 July is not particularly stable, and one of the parties leaves the government on 10 October. This would be coded as the End date - the government would have been in office for 74 days, from 29 July through 10 October. Then, on 11 October, we would have coded the Begin date for the next government, since the party composition had changed and the government now consisted of two parties rather than three. In cases in which a government (or prime minister) resigns, we code the date of government termination as the date of the acceptance of the resignation rather than the date of its announcement. This is because some announced resignations are not accepted; until a resignation is accepted, the government can continue to govern as before.

The approach we take for determining the date on which a government ends varies significantly from that taken by MRFH. ${ }^{8}$ For instance, in the hypothetical scenario mentioned above, we would have coded a government as ending when elections were held on 15 June. According to the MRFH coding rules, however, that government would not have ended until 28 July the day before the new cabinet took office. Note that the approach that we take to coding government terminations allows us to measure delays in government formation as well as to identify caretaker governments that would be otherwise overlooked. We would consider the period from 16 June-28 July (the days between the election and the formation of a new, duly-constituted government) as a continuation caretaker period - that is, a period when the incumbent government was continuing in office but no longer enjoyed its full mandate.

According to our data, there is often a lag (of days, weeks or even months) between the date of termination of one government and the date on which the next government takes office. As a result, the duration of many party governments in our data, where Actual duration is calculated as the number of days from the date the government takes office to the date of the government termination, varies from those in the MRFH data. The fact that many scholars routinely use data that do not explicitly measure the gap between the end of one government and the beginning of the next may explain why there are few published studies explaining the length of time it takes new governments to form. In the first of only a handful of studies of the length of time it takes new governments to form, Diermeier \& van Roozendaal (1998: 617) point out that the "termination of one cabinet means that a new formation process has to be 
started, resulting in a new cabinet after some period of time' and they go on to note that ' $[\mathrm{w}]$ hile this point may seem rather obvious, it is frequently ignored in the calculation of cabinet durations'. The implication is that government formation delays are largely invisible because of the way most scholars conceptualise and measure government duration. Diermeier \& van Roozendaal refer in particular to calculations of government duration by Woldendorp et al. (1993) - the model for the MRFH dataset.

In addition to the dates on which governments begin and end, and the length of time a government is in office, our dataset also provides information about how each government ends. In line with the majority of the literature on parliamentary governments, we classify government terminations into six different categories (Browne et al. 1984; King et al. 1990; Müller-Rommel, et al. 2004; Strøm 1990; Woldendorp et al. 1998): legislative elections; resignation of prime minister; change of party composition; resignation of cabinet; successful no confidence vote; or death of prime minister. We also provide some information about each government's type, since many studies of government duration or stability rely on such data as well. Consistent with Woldendorp et al. $(1998,2000)$ and Müller-Rommel et al. (2004), we classify each observation according to different government types. Although our labels are slightly different from those used in past research, our conceptualisations are similar: single-party majority government (one party in government that controls a parliamentary majority); minimal-winning coalition government (each party in government is needed to maintain a parliamentary majority); surplus coalition government (at least one party in government is not needed to maintain a parliamentary majority); single-party minority government (one party in government that does not control a parliamentary majority); or minority coalition government (multiple parties in government that together do not control a parliamentary majority).

The MRHF article does include several caretaker governments. Specifically, it includes what we call new caretaker governments. These are often included in datasets of parliamentary governments, whereas continuation caretaker governments are typically ignored altogether in most analyses and datasets. When a temporary prime minister is publicly appointed for an interim period until a duly-constituted cabinet can be formed, we refer to this cabinet as a new caretaker government. That is, if the cabinet begins its life with caretaker status, we consider it to be a new caretaker cabinet (Warwick 1996). It is not unusual for the new caretaker prime minister to be nonpartisan; sometimes the entire caretaker government is nonpartisan. For example, when Reneta Indzhova was appointed as 'acting' prime minister in Bulgaria in mid-October 1994, she was explicitly appointed to lead a nonpartisan interim government, and her caretaker government stayed in office for only three months. 
However, new caretaker governments are not the only governments that do not have a full mandate to enact policy. Usually overlooked by scholars are the continuation caretaker governments, which are composed of outgoing governments that have lost their mandates due to a new election or a government resignation. We believe that it is important to be able to take account of all caretaker government periods, whether they are new or continuation cabinets. Note that the structure of our data allows us to do this. For instance, going back to the hypothetical scenario described above, we noted that the outgoing cabinet would have been transformed into a continuation caretaker government following the election on 15 June and would have remained in office until the duly-mandated government took office on 29 July. Such a continuation caretaker government would most likely be in charge of running some dayto-day affairs, but presumably would not be able to implement any significant policy changes for that month and a half. Taking account of the presence and duration of caretaker governments is important because the literature on parliamentary democracies suggests that caretaker governments do not typically work to pass new policy or revise existing law; rather, 'it is accepted that these governments have a limited life-span and limited freedom of action' (Herman \& Pope 1973: 196). Caretaker governments are expected to expend only minimal effort to keep the government functioning until the next dulyconstituted cabinet comes to power. We discuss caretaker governments, and their potential consequences, in more detail below.

In the data shown in the Appendix, the 118 duly-constituted, or dulymandated, governments in our eleven countries are presented temporally from the founding government within each country to the government in power as of 31 December 2008. For each government, we include a Begin date (the date of installation of the government) and, for all governments that ended prior to 31 December 2008, an End date (the date of termination of the government). The Actual duration measure, then, is the number of days from the Begin date to the End date. Along with the actual duration, we provide the maximum Potential duration - that is, the number of days comprising the remainder of the parliamentary term (Müller \& Strøm 2000a: 17). The potential duration, which is calculated as the number of days from the Begin date to the date of the next constitutionally mandated parliamentary election, shows the maximum potential term in office that each government could enjoy. The legislative term is four years for each of the eleven countries in our sample. ${ }^{9}$ This allows observers to distinguish between two governments with actual durations of 250 days, but in one case the potential duration was only 265 days and in the other the potential duration was 1,400 days. In the latter case, it seems clear that the government was unstable; it is more difficult to make inferences about the short duration of the former example. Indeed, the former 
government might well have been able to stay in office for several more years; we simply do not know how many days beyond 250 it would have remained in office if no constitutionally mandated election were looming.

We provide the names of the parties in each government as well as the name and partisan affiliation of the prime minister. One completely new feature of our dataset is that we also include the number of days between the End date of a cabinet and the Begin date of the next duly-constituted cabinet. This gap between duly-mandated governments is broken into continuation and new caretaker periods. ${ }^{10}$ This allows the reader to see at a glance which countries are prone to delays between duly-constituted governments. Of course, it is easy to use our data to calculate government durations the way that MRFH do, so any scholar who found their conceptualisation of government duration to be the appropriate one could simply calculate the number of days between the Begin date of government $i$ and the day prior to the Begin date of government $i+1$ to create the MRFH duration measure. Below, we present several measures of duration and stability for the countries in our dataset, and discuss their potential uses.

\section{Government duration and stability in Central Eastern Europe}

Using the new dataset from 1990-2008, we can compare the eleven countries using a variety of measures, beginning with a comparison between the MRFH measure of government duration and the new measure that we have proposed. As we mentioned above, the MRFH measure is created by calculating the length of time that elapses between the beginning of one government and the start of the next one. When we compare the two measures, we see that the average government duration for each country is always shorter with the new measure than with the MRFH measure, as one would expect. Table 1 below shows the average duration (according to both measures) in days for all eleven countries.

The first three columns of government duration information are for all governments, including new caretaker ones. Recall that many scholars include new caretaker governments in their analyses; we provide this information to make our results more directly comparable to theirs. However, it could be argued that interim, or caretaker, governments by their very nature occur in situations in which governing processes are not functioning normally, and that as a result we should be even more stringent and limit our assessment of stability to those governments that begin life with a proper mandate. The most appropriate measure, then, might exclude all caretaker governments and rely only on data from governments with proper mandates. Restricting our 


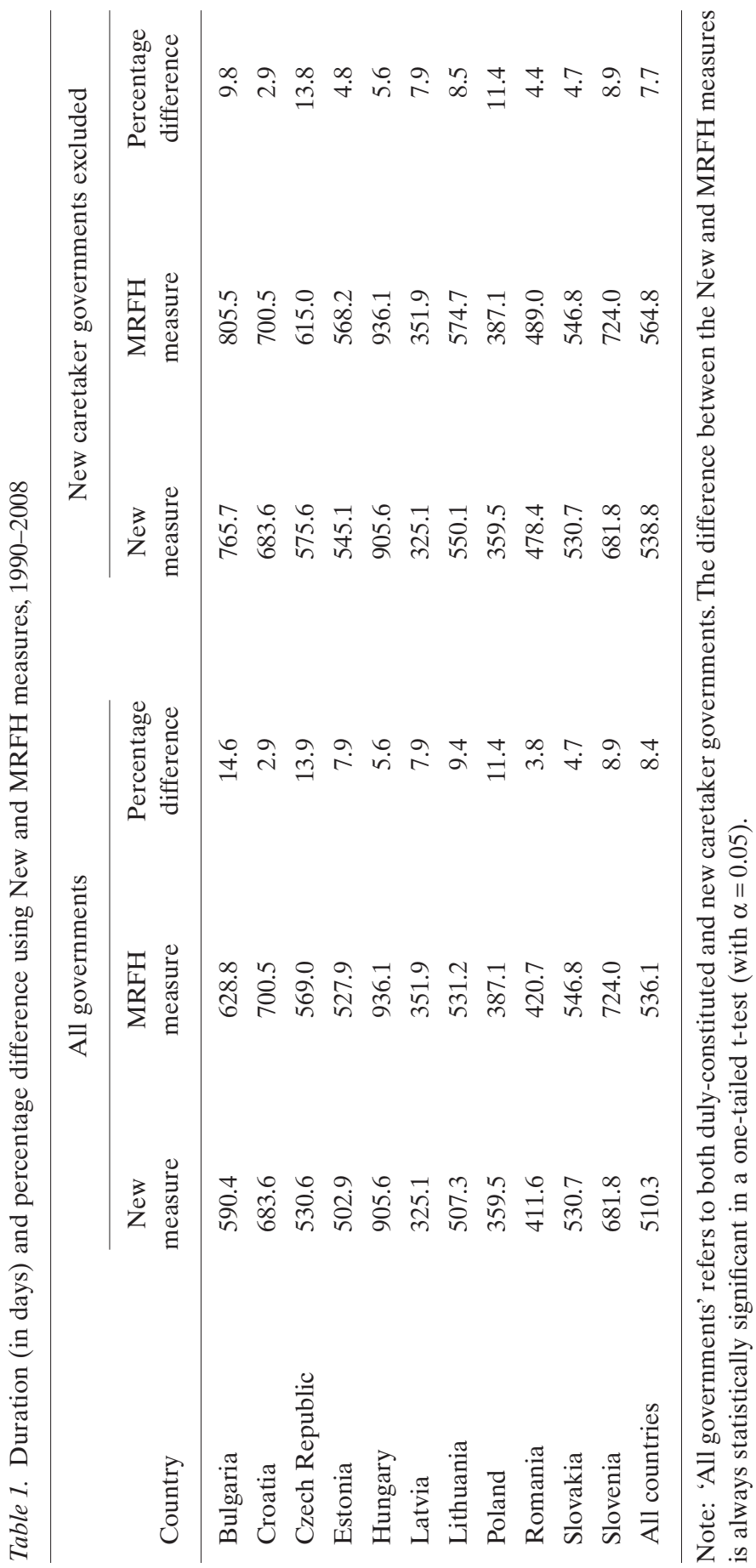


attention in this way to duly-constituted governments requires eliminating new caretaker governments from our analysis altogether. Information on the average durations of duly-mandated governments only is shown in the final three columns. Note that only some of the countries in the dataset experienced new caretaker governments: Bulgaria and Romania had two each; and the Czech Republic, Estonia and Lithuania each had one. Thus for the six remaining countries, the results in Table 1 are the same regardless of whether new caretaker governments are included or not.

Interestingly, for some countries the difference between the MRFH and new measures is much larger than it is for others. Contrast Croatia, with a difference between the two measures that is not quite 3 per cent, and the Czech Republic, with a difference of nearly 14 per cent. Obviously the Czech Republic has more experience with continuation caretaker periods than Croatia does, suggesting that duly-mandated governments take a particularly long time to form in the Czech Republic compared to some other countries in the region. Poland, similarly, has a large gap between the new duration measure and the MRFH measure.

To focus more directly on the periods without duly mandated governments, we propose an additional measure. The flip side of the measures of stability, in terms of government duration, are measures of instability, or crisis (Mershon 2002). What happens when we focus on the periods in which there is no duly-constituted government in office? Which countries routinely suffer bargaining delays during the government formation process? If we take the idea seriously that caretaker governments - both new and continuation - might be qualitatively different when compared to duly-constituted governments, then we need to have data that would allow us to explore empirically whether these governments do in fact behave differently.

The Crisis percentage measure in Table 2 shows the percentage of time each country spent without a duly-constituted government in the time period under investigation here. Take Poland as an example. The first Polish government took office on 23 December 1991. Between that date and 31 December 2008, Polish citizens experienced 414 days (6.7 per cent of the total period of 6,219 days) without a duly-mandated government in office. Table 2 also shows a Performance index measure that provides information based on yet another way of conceptualising government stability. This measure is the average percentage of the potential term in office that governments actually fulfill - that is, if a government is in office for 200 days and the next constitutionally mandated election is 1,000 days away at the start of the government's term, the performance index is 20 per cent. However, if a government is in office for 200 days and the next constitutionally mandated legislative election is only 250 days away, then the government's performance index is 80 per cent. We show the 
average performance index for all governments (both duly-mandated and new caretaker ones) as well as for duly-mandated governments only.

Hungary has both a low crisis percentage and a high performance index, indicating that Hungarian governments are quite stable. There is little time that elapses between duly-mandated governments, and once in office, governments serve out most of their potentially remaining term. Latvia, on the other hand, has a fairly high crisis percentage average and scores poorly on the performance index, suggesting that governments take a long time to form and that once in office, they fail quickly. For some countries, then, these two measures of stability - Crisis percentage and Performance index - seem to provide similar information about the stability of a country's governments. Indeed, these observations about both Hungary and Latvia are in keeping with the duration measures for both countries provided in Table 1. However, consider Romania and Slovakia. Both have quite low crisis percentages, indicating that they spend very little time without duly-mandated governments, but both also have fairly low scores on the performance index. Thus, although neither suffers from long government formation periods, both have governments that end quite quickly instead of approaching their full potential mandates. This highlights the fact that crisis

Table 2. Alternative government stability measures, 1990-2008

\begin{tabular}{lccc}
\hline & & \multicolumn{2}{c}{ Performance index } \\
\cline { 3 - 4 } Country & $\begin{array}{c}\text { Crisis } \\
\text { percentage }\end{array}$ & $\begin{array}{c}\text { All } \\
\text { governments }\end{array}$ & $\begin{array}{c}\text { New caretaker } \\
\text { governments excluded }\end{array}$ \\
\hline Bulgaria & 7.0 & 51.3 & 64.3 \\
Croatia & 2.3 & 60.9 & 60.9 \\
Czech Republic & 8.8 & 49.4 & 53.3 \\
Estonia & 6.3 & 55.6 & 59.0 \\
Hungary & 3.1 & 83.1 & 83.1 \\
Latvia & 7.2 & 46.8 & 46.8 \\
Lithuania & 5.8 & 53.9 & 58.8 \\
Poland & 6.7 & 39.5 & 39.5 \\
Romania & 2.5 & 43.8 & 50.8 \\
Slovakia & 2.5 & 48.4 & 48.4 \\
Slovenia & 5.8 & 75.9 & 75.9 \\
All countries & 5.2 & 52.8 & 55.6 \\
\hline
\end{tabular}

Note: 'All governments' refers to both duly-constituted and new caretaker governments. 'Crisis percentage' refers to the percentage of time spent without duly-mandated governments. 'Performance index' refers to the average percentage of the potential term that governments actually fulfill. 
percentages and performance indexes are, indeed, capturing different aspects of government stability. The alternative stability measures shown here suggest a number of questions. For instance, why do some countries, such as Bulgaria and Estonia, spend so much more time without a duly-mandated government than other countries, such as Romania or Croatia?

For a slightly different take on these same data, instead of comparing across countries, we could compare different government types. In Table 3, we show average government durations according to both the new and the MRFH measures, the percentage difference between them and the performance index for five different government types: three majority (single-party majority, minimal-winning coalition and surplus coalition) and two minority (singleparty minority and minority coalition). Our sample sizes, particularly in some categories, are decidedly modest. However, the fact that majority governments are, on average, more stable than minority ones, and that single-party majority governments are especially stable, should not come as a surprise given the extant findings in the literature on parliamentary governments.

It is interesting to note, however, that the standard way of calculating government duration, which ignores periods of continuation caretaker governments, seems to understate the importance of majority versus minority status for government duration. This is demonstrated by the particularly stark percentage difference between the new and MRFH measures for minority governments compared with majority ones. The extent to which minority governments have shorter durations than majority governments, and the extent to which minority governments are followed by long periods of caretaker governments, is obscured if one uses the MRFH measure.

\section{The importance of caretaker governments}

The results presented in the three tables above underscore the importance of choosing the most appropriate measure for the underlying concept of government stability one is interested in examining. In particular, whether or not a scholar includes 'new' caretaker governments in the data might affect the analyses to be performed. The new measure presented in this article would be particularly useful if one wanted to focus on questions concerning the consequences of caretaker governments, which are often assumed to be pernicious but have not yet been studied in a systematic fashion. With the new data and different measures of stability provided here, one could examine the causes and consequences of caretaker governments as well as the different kinds of instability that can plague parliamentary governments, such as delays in the formation of new governments. 


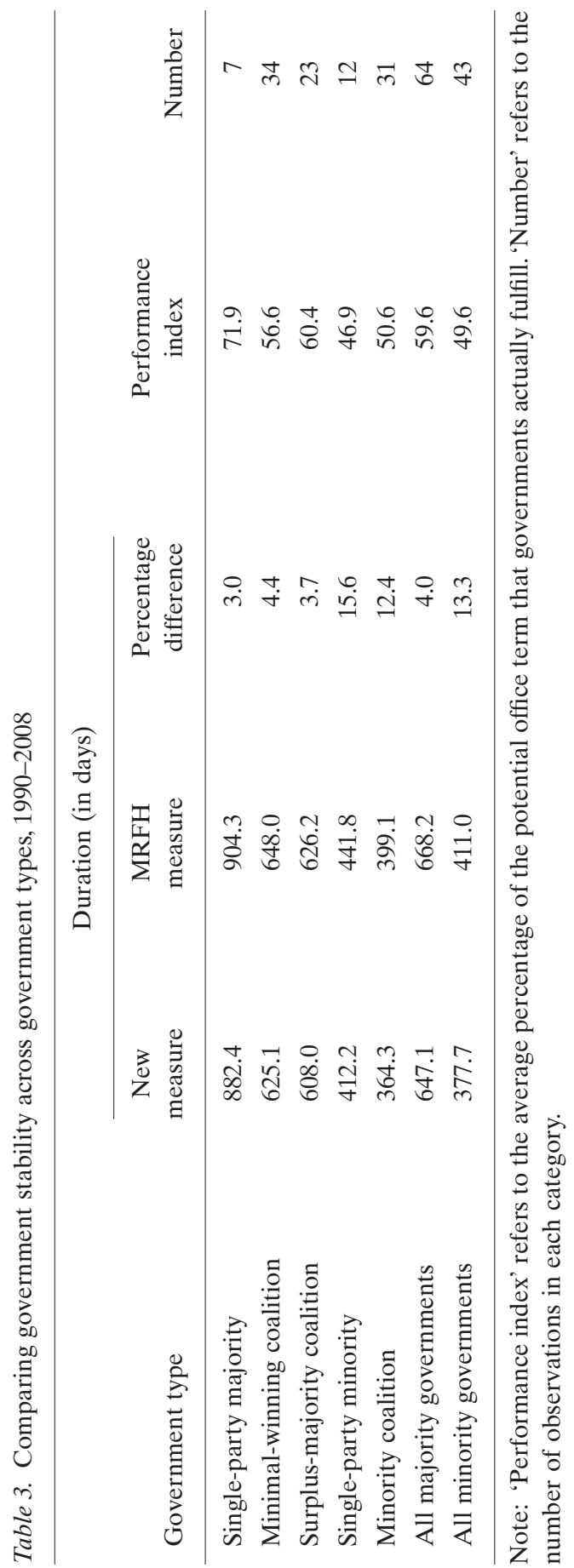


Perceived government legitimacy can easily be undermined under caretaker governments, either because a government without a mandate is implementing policy, or because a government's inaction is seen as undermining the public interest. For a recent example, consider the seven-month delay in forming a stable government following the June 2006 legislative elections in the Czech Republic. Two months after the elections, the Czech media were already sounding grim warnings regarding the consequences of the sustained tenure of the caretaker government: 'Lawmakers are getting nothing done, while legislation and important reforms rest in a state of limbo, including long awaited pension reform, the privatisation of many state-owned companies, an overhaul of the country's Criminal Code and the fate of the controversial flat tax. A nonfunctioning Parliament costs taxpayers as much as 3 million Kč (US\$136,550) a day' (The Prague Post Online, 24 August 2006). A new government formed under Mirek Topolanek in September 2007, but it was shortlived; after failing to pass the investiture vote, the cabinet was forced to step down. After further delay, another government with Topolanek as prime minister finally managed to pass an investiture vote on 19 January 2007 - nearly 230 days after the legislative elections had originally taken place. If we had been using the MRFH coding rules, then the period from June to September would simply have been coded as part of the previous government, led by Jiri Paroubek, and the three month period between the two Topolanek governments also would have been invisible. Without a way to provide information about the caretaker periods, it would be hard to make sense of media reports or other indicators of economic and political unrest in the Czech Republic during this time. An increasing number of studies have suggested that the uncertainty generated by long delays in forming governments might have adverse effects on economic outcomes. If these studies are correct, then it is troubling that most of our commonly used datasets do not allow us to easily identify, let alone examine, the causes and consequences of periods without duly-constituted governments.

We are unaware of any cross-national studies that have focused directly on the characteristics of caretaker governments, although several empirical studies point to problems that are associated with protracted caretaker periods. For example, coalition scholars sometimes use the length of time between governments to measure 'crisis duration' - a factor thought to influence the stability of the next government that forms (Mershon 2002). Other scholars examine economic outcomes during the 'crisis', or caretaker, periods following elections. In such cases, uncertainty over the government formation process can affect exchange rate markets (Bernhard \& Leblang 2002), stock market volatility (Leblang \& Mukherjee 2005) and the types of assets in which market actors choose to invest (Bernhard \& Leblang 2006). When delays in the 
formation of duly-mandated governments are drawn out, the related uncertainty regarding the likely direction of future policy has deleterious economic consequences (Martin \& Vanberg 2003: 323-324). The implication of these studies is that caretaker governments are unable (or unwilling) to implement lasting policies and thus economic actors react to the resultant political uncertainty with increased speculation. ${ }^{11}$

Although there seems to be a vague consensus in the political science literature that caretaker governments do (or ought to) behave differently from duly-constituted governments, we have no systematic data or studies demonstrating the ways in which they are different or how the capacity of caretaker governments to act varies by country. ${ }^{12}$ Anecdotal evidence suggests that ministers in caretaker governments in different countries react differently to their status as 'placeholders' while waiting for a government with a proper mandate to take over. Although pushing new legislation through parliament after a government has lost a vote of confidence might be highly impractical (if not impossible), implementing changes in policy via the bureaucracy might remain a feasible option for the members of some caretaker governments. ${ }^{13}$ The studies mentioned here, outlining the political and economic consequences that can occur during the tenure of caretaker governments, suggest that variation in how caretaker governments can act might be consequential. As Laver \& Shepsle (1994: 292) argue: 'It is important ... to be aware of the policy implications of having a caretaker government in power. Surprisingly, this is a matter that has been more or less ignored by the literature on government formation.' Scholars wishing to contribute to research in this area would need to use a measure of government duration like the one we provide here; alternative measures that do not allow for distinctions between duly-mandated and continuation caretaker governments would not suffice.

\section{Conclusion}

For some research questions, the measure of government duration we have presented here is a more appropriate choice than the one provided by MRFH. For instance, if someone wanted to study the determinants of delays in government formation, it would be impossible to do so with the MRFH measure, but it could be done easily with the new measure presented in this article. If someone wished to study the effects of caretaker governments and wanted to be able to compare new caretaker governments with continuation ones, then the new measure would also be preferable. This is not to say that one would necessarily always choose our measure over the MRFH one; there are certainly questions for which that measure is entirely appropriate and might be 
the better choice. We do not wish to suggest otherwise. What we do want to suggest is that scholars should explicitly consider how well their data reflect the underlying concepts they care about as they decide which measures and operationalisations are most appropriate given the kinds of questions they are addressing.

Our data also provide an opportunity to investigate which of our inferences are robust to empirical evaluations when conducted with a variety of measures, and which are sensitive to the measure that is chosen. For instance, if ideological polarisation within the legislature strongly contributes to instability according to one measure but has no effect if we use a different one, this might suggest some interesting theoretical arguments about the role of ideological polarisation and government formation and duration. If deleterious economic consequences result from frequent and lengthy caretaker periods rather than from a succession of governments that terminate quickly (but that are followed almost immediately by new duly-mandated governments), then we could offer some important policy advice to countries plagued by certain types of instability. In short, we hope that scholars interested in a variety of aspects of the governmental life cycle in parliamentary democracies (and particularly in the new democracies in Central Eastern Europe) find this new dataset to be a useful tool for exploring some of the questions suggested here.

\section{Acknowledgements}

Thanks to Matt Golder, Monika Nalepa, Ben Nyblade, Andrew Roberts, Rob Salmond, participants at the 2008 Midwest Political Science Association Meeting in Chicago, and several anonymous reviewers for helpful comments and criticisms. A detailed codebook identifying the sources used to create the dataset, along with all of the data and computer code necessary to replicate the descriptive statistics in this article, will be made available at the authors' webpages on publication.

\section{Appendix}

In this section, we provide detailed information on the duly-constituted, or duly-mandated, governments that have held office in the eleven Eastern European countries in our sample. Each table contains the following information:

Number: Number identifying each duly-constituted government cabinet within a country. 
Begin date: The date on which the cabinet takes office.

End date: The date on which the cabinet's term in office terminates.

Potential duration (in days): Maximum number of days the cabinet could be in office, measured from the Begin date until the next constitutionallymandated date of parliamentary elections. If elections are held over a two-day period or over multiple rounds, then we use the final election day.

Actual duration (in days): Number of days the cabinet is in office, measured from the Begin date to the End date.

Type of government: Identifies the type of government, coded as follows: 1 = single-party majority; $2=$ minimal-winning coalition; $3=$ surplus majority; $4=$ single party minority; $5=$ minority coalition.

End type: Identifies the reason for the government's termination, coded as follows: 1 =legislative elections; 2 =resignation of prime minister; $3=$ change of party composition; $4=$ resignation of cabinet; $5=$ successful no-confidence vote; $6=$ death of prime minister.

Succeeding caretaker period (in days): Number of days following the End date of current duly-constituted government until the Begin date of the next duly-constituted government. The caretaker periods are divided into continuation caretaker government periods and new caretaker government periods.

Parties in government: Identity of parties in government. Party of the prime minister is indicated in bold typeface.

Prime minister: Name of prime minister. 


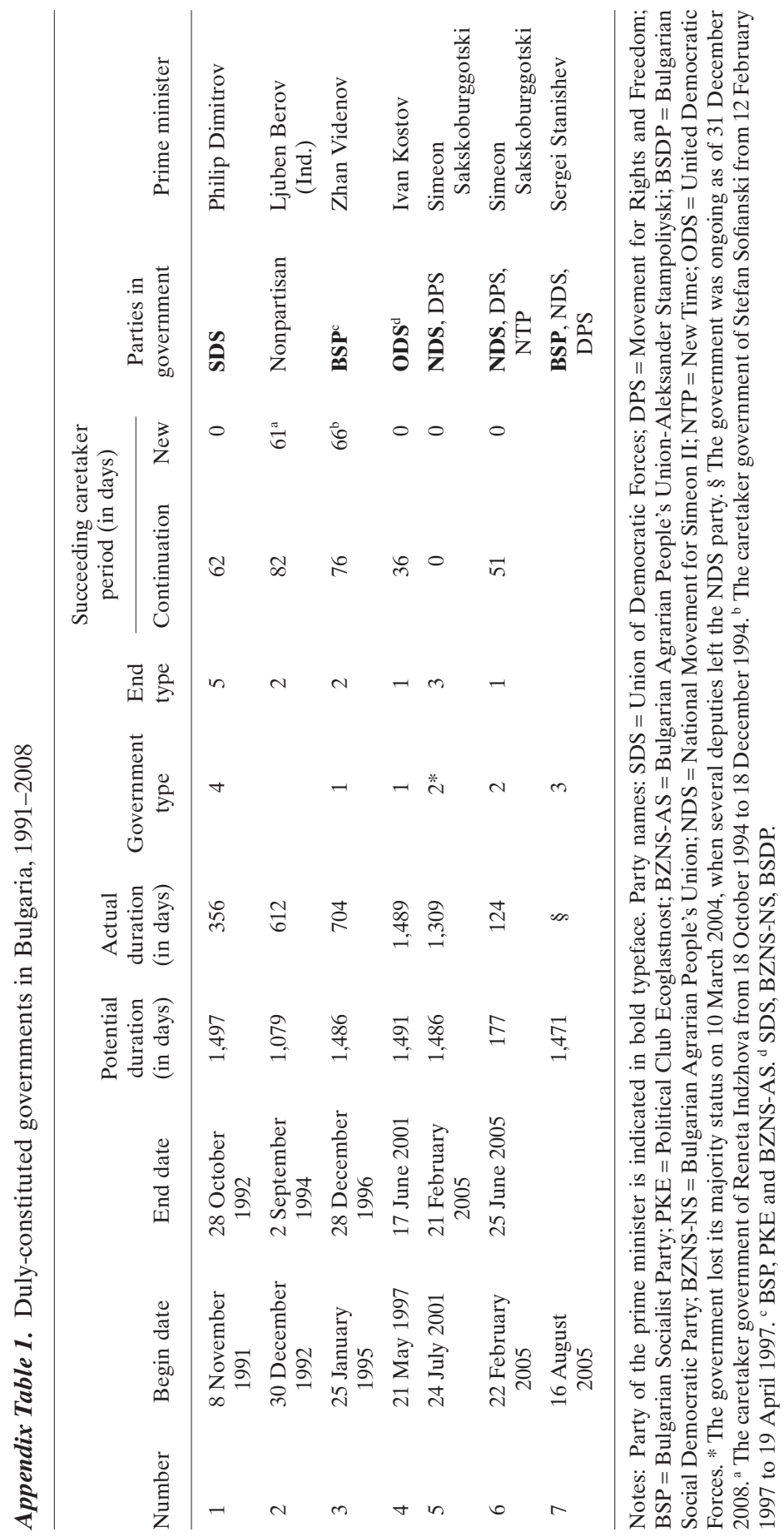




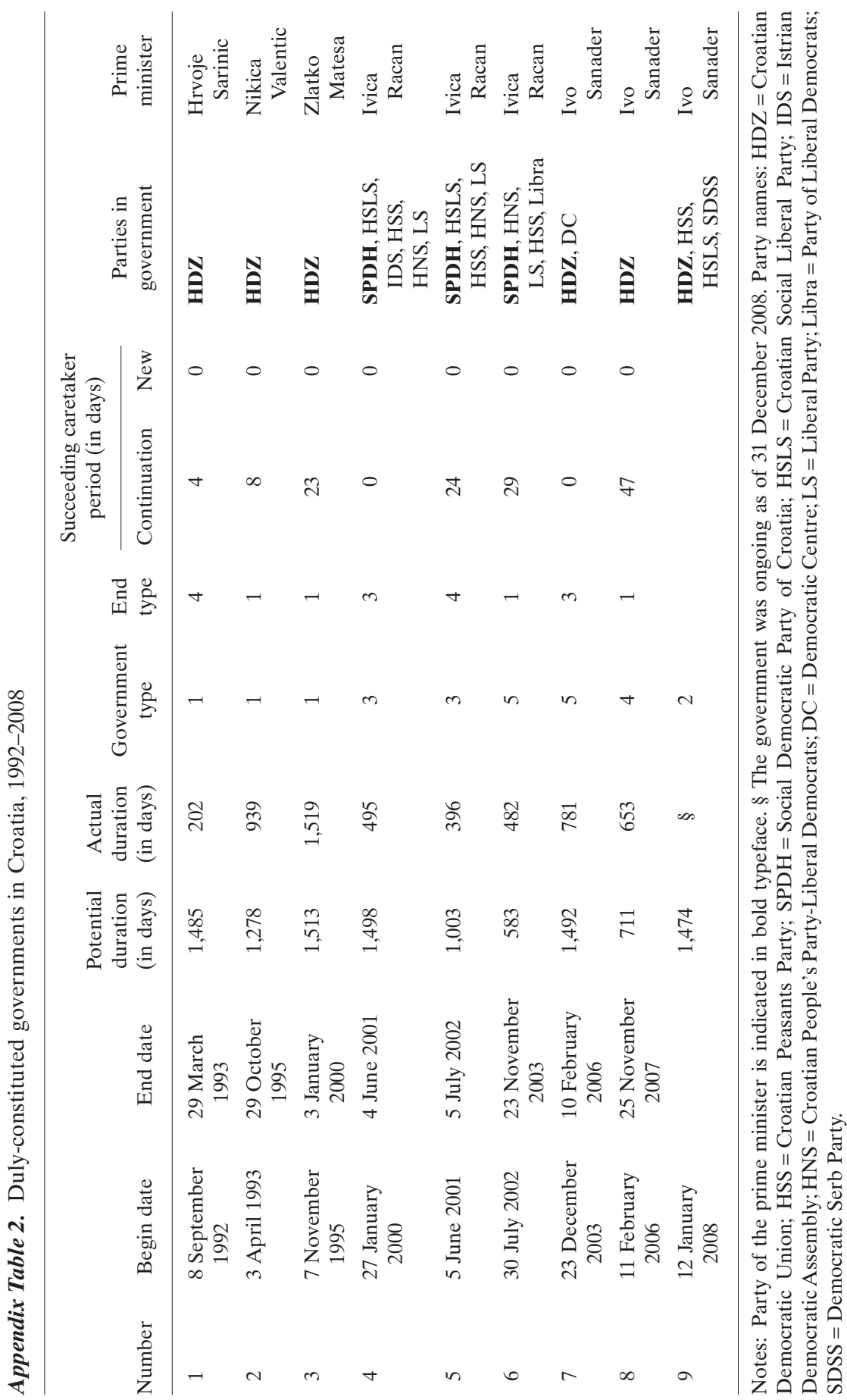

(c) 2009 The Author(s) Journal compilation (C) 2009 (European Consortium for Political Research) 


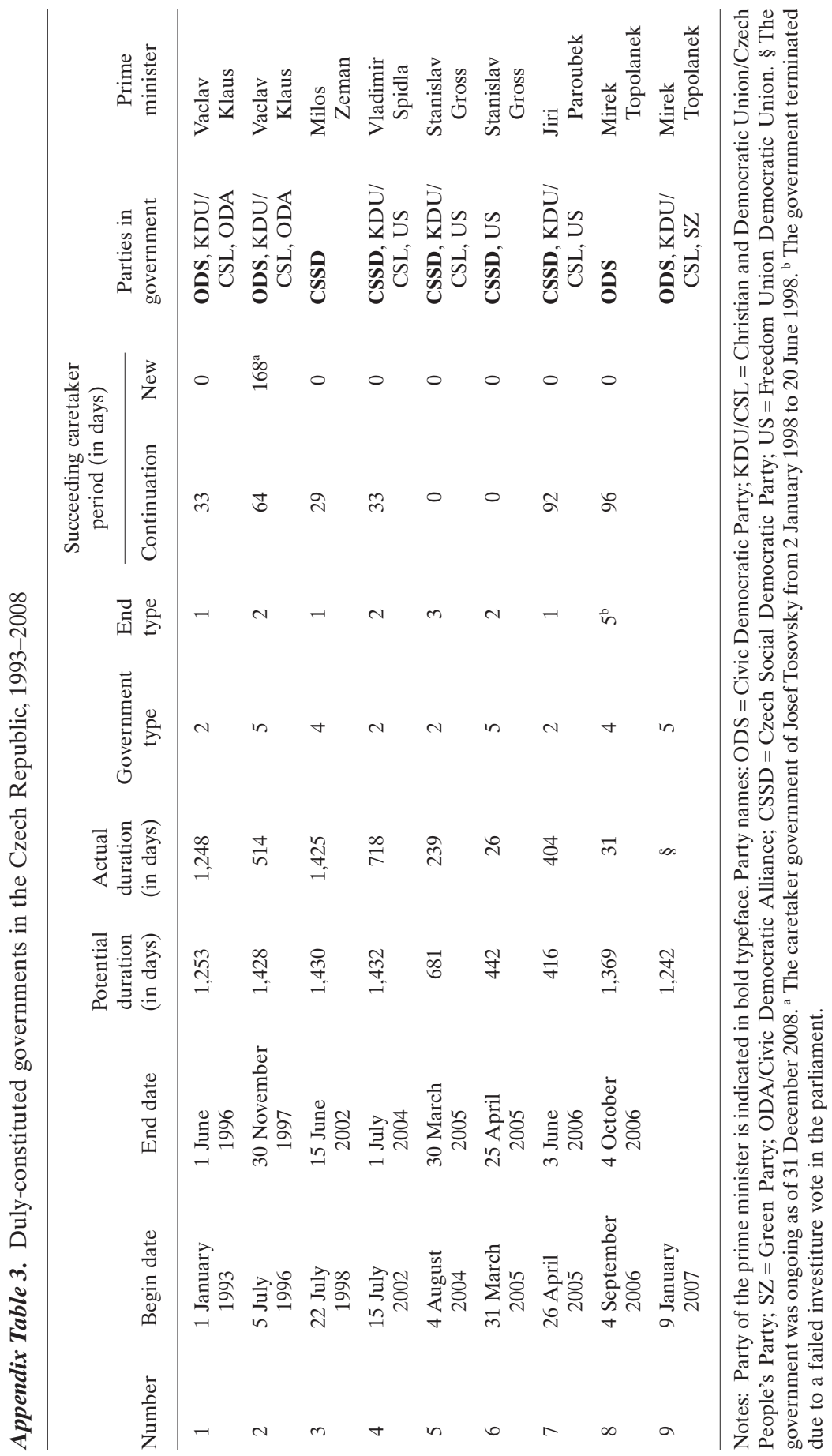




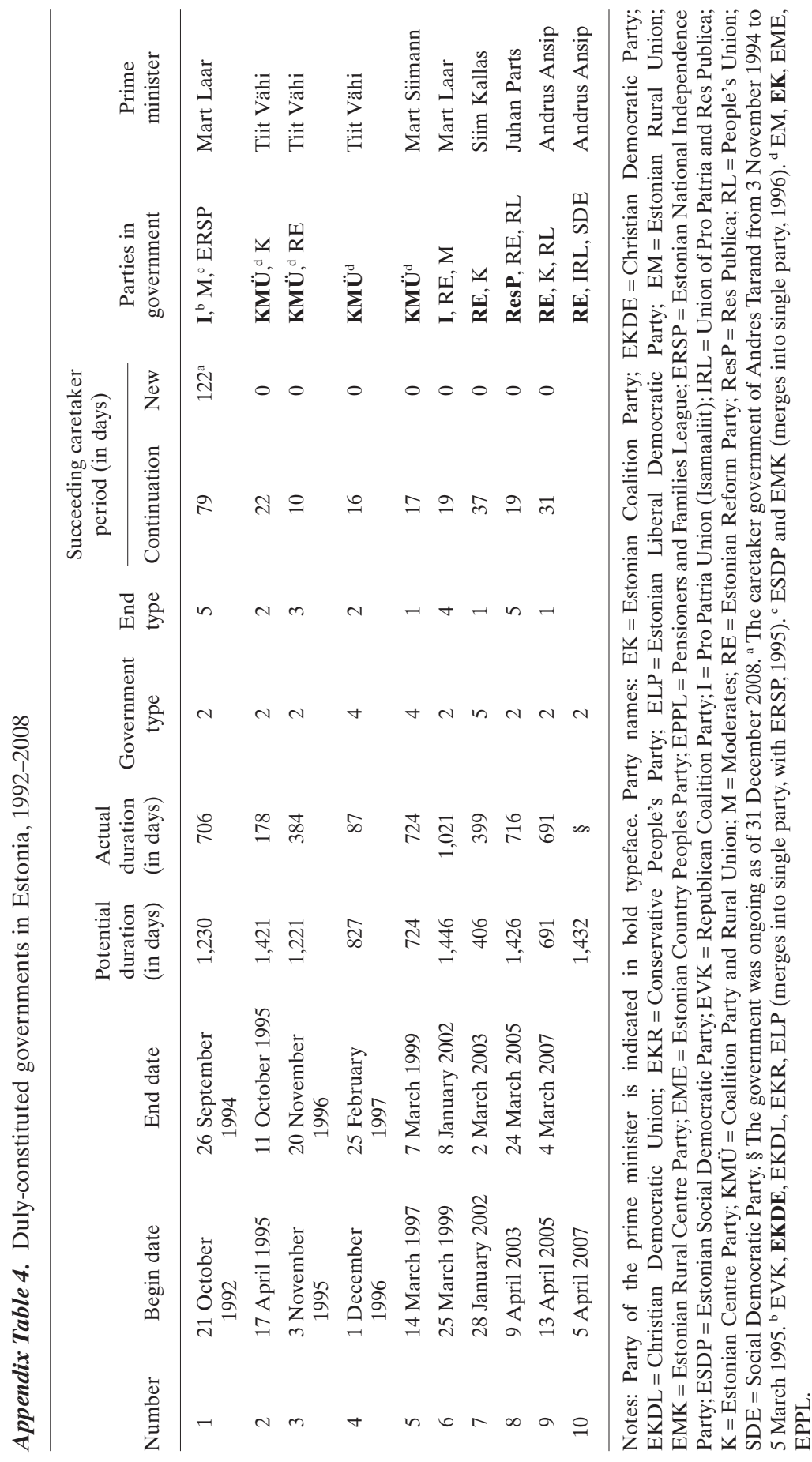




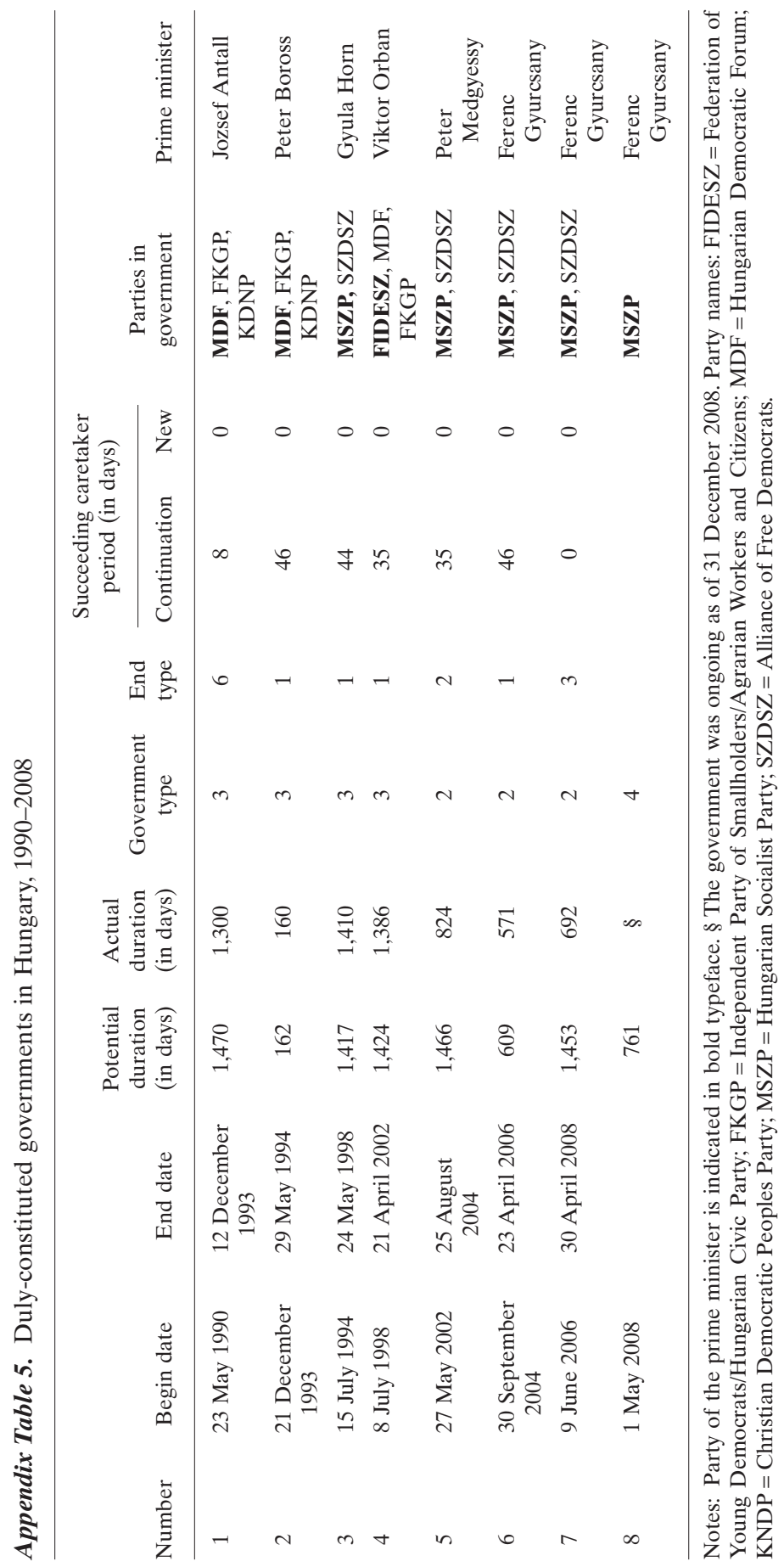




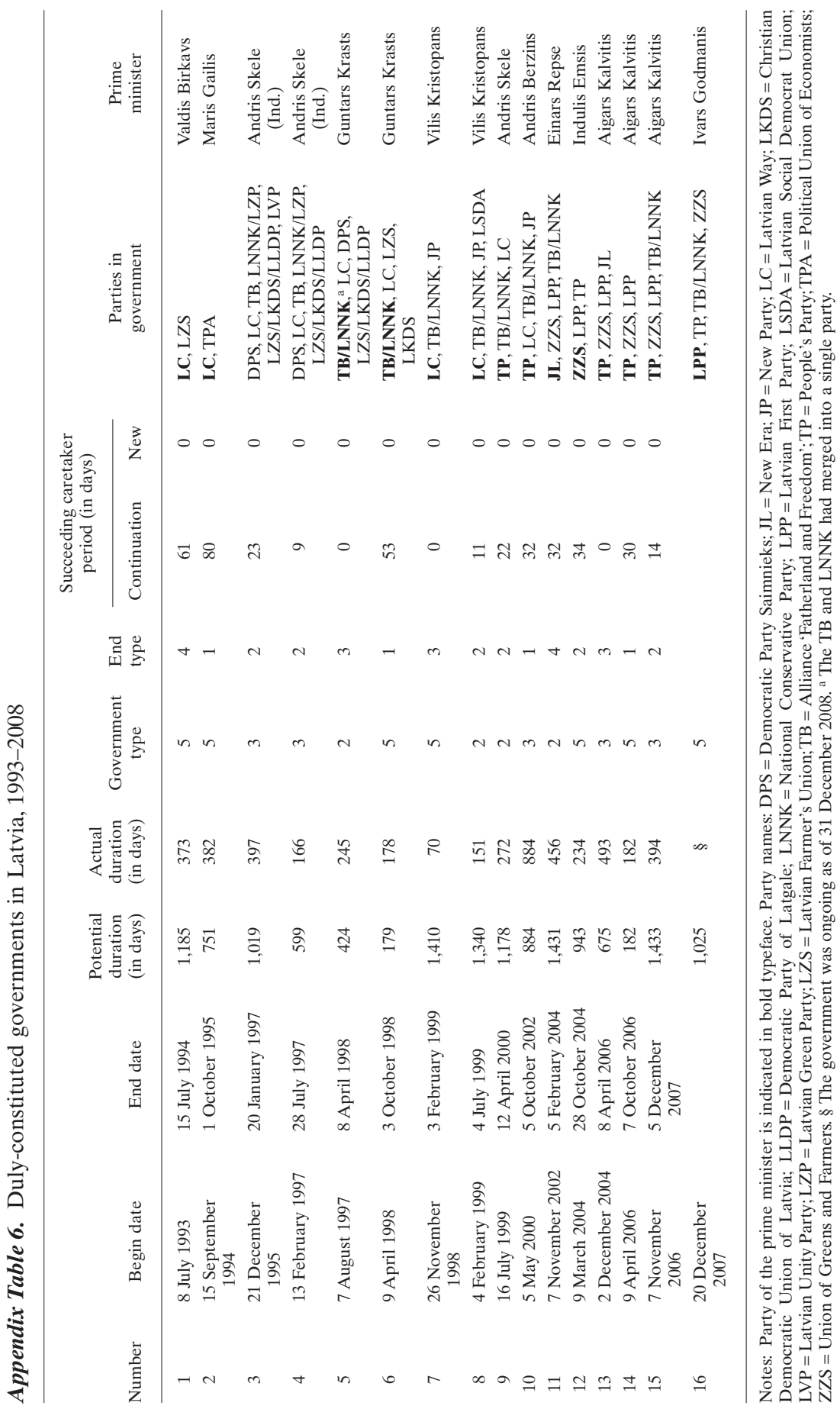




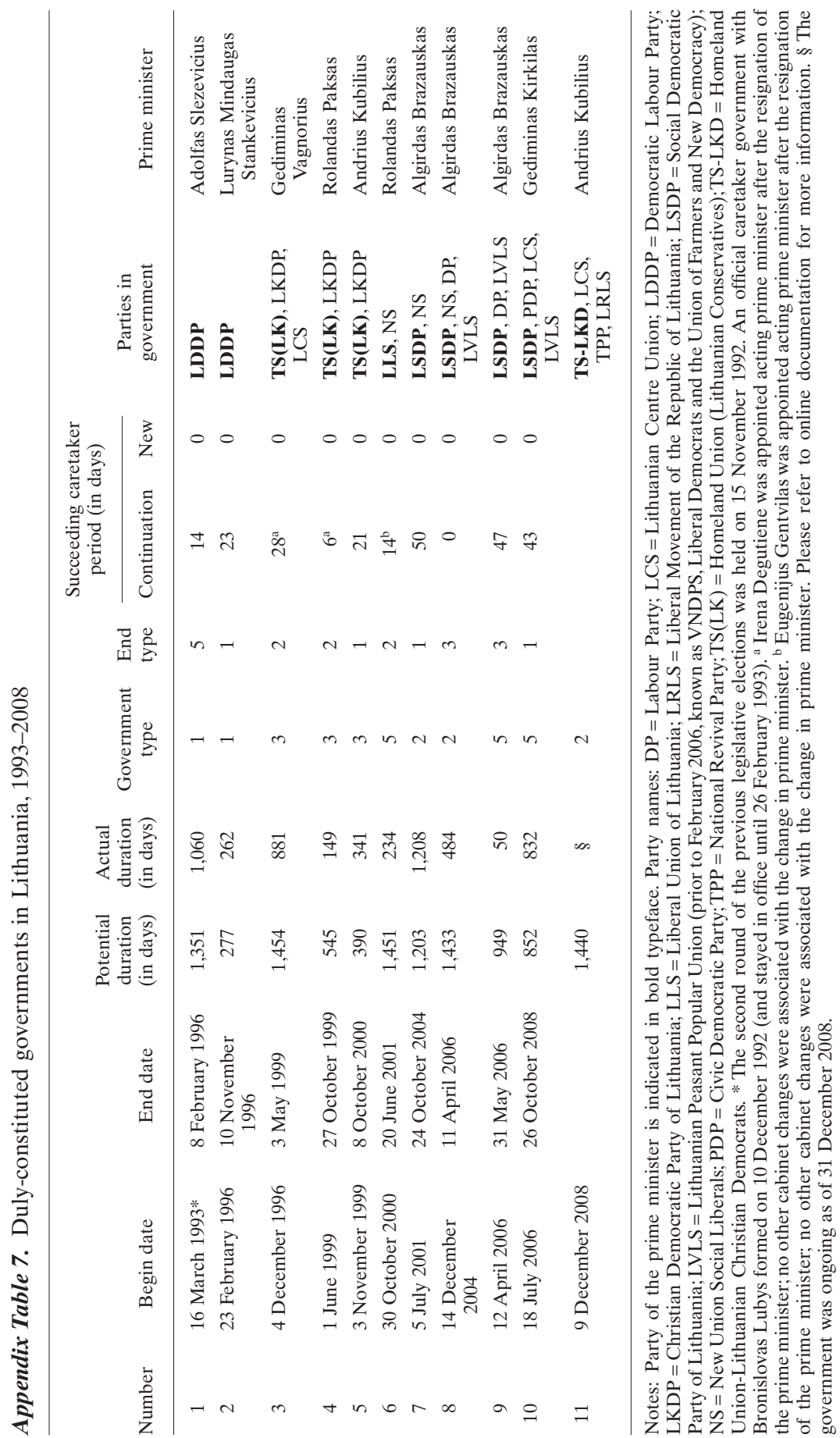




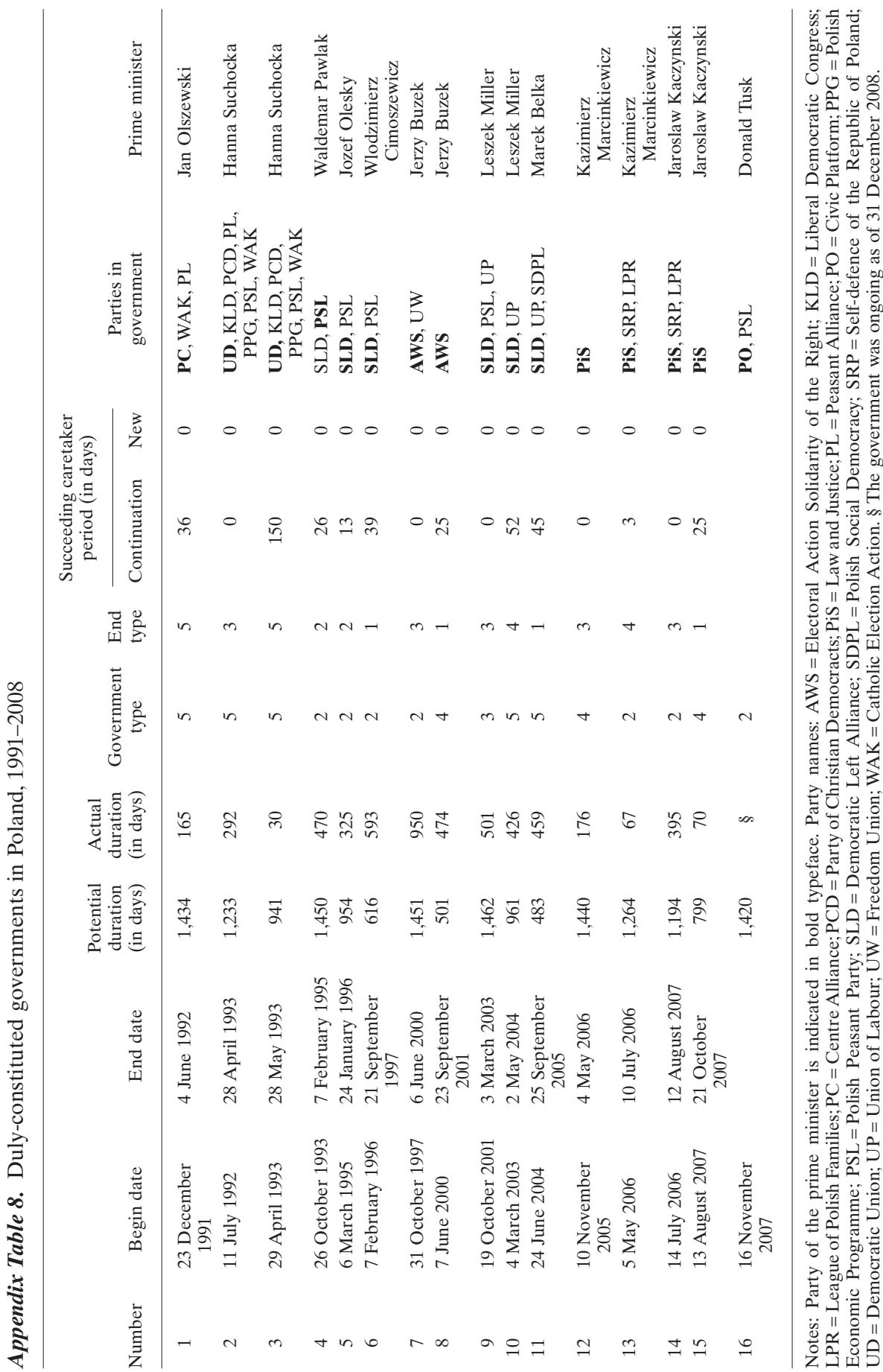









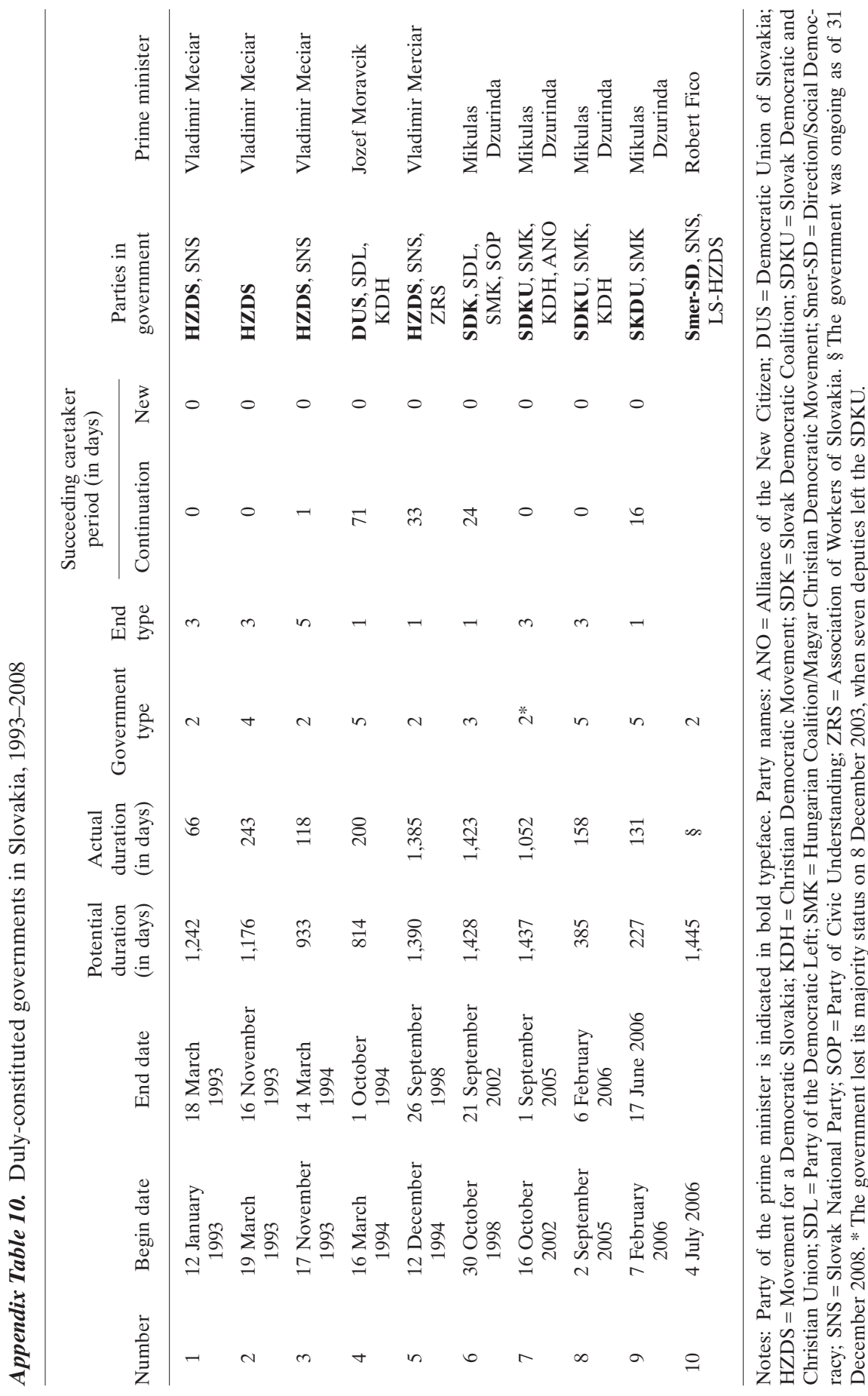




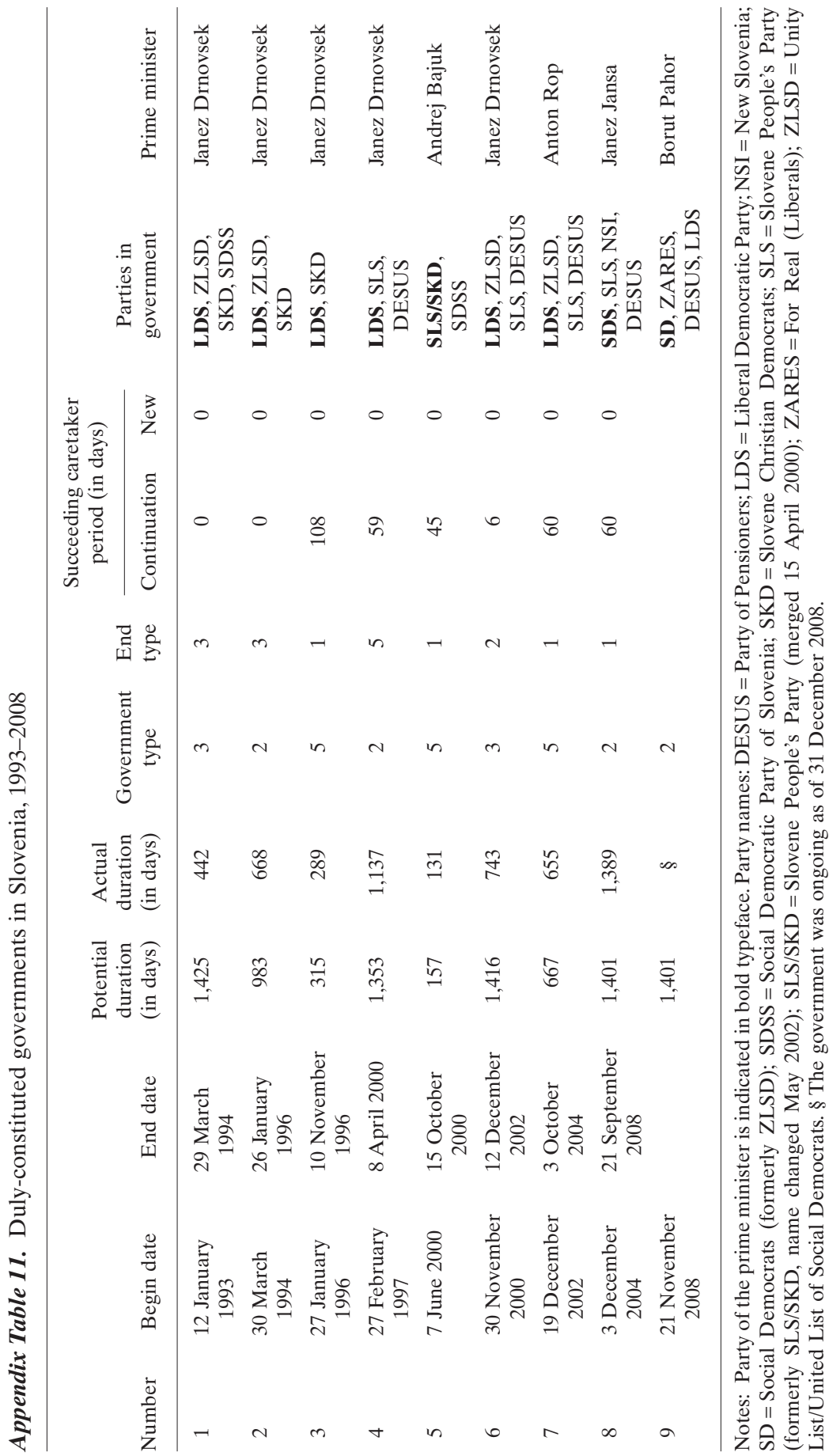




\section{Notes}

1. Note that we are not suggesting that our measure is necessarily superior to the one proposed by MRFH. Rather, we are arguing that for some questions, one of these measures will likely be more appropriate than the other.

2. See, e.g., Ikstens (2008); Krupavicius (2007); Linek (2006); Malová and Učeň (2007); Pettai (2008); Spirova (2008); Stan and Zaharia (2008).

3. These sources are described in more detail in an online appendix on the authors' websites at: http://polisci.fsu.edu/people/faculty/sgolder.htm and http://myweb.fsu.edu/ cnr05e/Courtenay_Ryals/Home.html. The appendix of data sources lists the sources used to determine the dates each government was in office as well as its party composition, among other government characteristics.

4. MRFH (2004) provide data through 2003 (Müller-Rommel et al. 2004).

5. Although we adopt the same criteria, our founding government dates for Croatia ( 8 September 1992) and Latvia (20 July 1993) differ slightly from those of MRFH (12 August 1992 and 4 July 1993, respectively) because we followed the dates provided in both Keesings World News Archive and Banks et al. (2006).

6. Authors of government coalition datasets do not always provide precise information about their coding rules. However, one can always compare the dates in a particular dataset with information in Keesings World News Archive or some other source and figure out what the actual coding rules were. We should note that in some countries, the investiture vote and the government taking office happen at the same time, whereas in others the government is appointed and several weeks might go by before the government faces an investiture vote in the legislature.

7. We code the termination of a government ended by elections as occurring on the final day of elections in cases where elections take place over more than one day.

8. We follow the authors of the Parliamentary Democracy Data Archive (PDDA), a recent dataset covering democratic periods in 17 West European countries from 1944 to 1999 (Müller \& Strøm 2000b; Strøm et al. 2003). Unlike most datasets commonly used by government coalition scholars, the PDDA data use the date of a government resignation or an election as the end date of the government.

9. However, Latvia did employ three-year legislative terms prior to the 1998 elections. Knowing that the legislative term is four years does not mean that calculating the date of the next election is as simple as adding four years to the date of the previous election. Rather, some constitutions specify constitutional interelection periods (CIEP) that are close, but not identical to, four years, and we took this into account when constructing this variable. For instance, although the Bulgarian Constitution states that the National Assembly is elected for a term of four years (Article 64, paragraph 1), it also specifies that elections for a new National Assembly have to be held within two months from the expiration of the mandate of the preceding Assembly (Article 64, paragraph 3). Similarly, Croatia allows a CIEP of four years plus sixty days, and Romania allows four years plus three months. Hungary has four-year terms, but elections are to be held in April or May in the fourth year following the previous parliament's election (Article 20, paragraph 1). Meanwhile, some countries, such as Poland, specify that the legislative term does not begin until the parliament holds its first sitting (Article 98, paragraph 1). According to Article 1 of the Procedural Rules of the Sejm, the first sitting is held at a time chosen by the Speaker (nominated by the President from among the members of parliament who are oldest by age), and thus the time that elapses between an election 
and the parliament's first sitting varies. (We are grateful to Monika Nalepa for providing information on the Sejm procedures.) The articles relevant for calculating the CIEP from the constitutions of the eleven countries are included in the online appendix that provides detailed information on data sources.

10. For any scholars who would prefer to include new caretaker governments in addition to duly-constituted governments for their own analyses, we provide information on all new caretaker governments in the replication files available on the authors' webpages. We provide the same information for these governments as we do for the duly-mandated governments listed in the appendix (begin date, end date, parties, name of prime minister, etc.).

11. Much of the political economy literature in this area focuses on how changes in the partisan composition of a government affects economic outcomes, but here we are interested in the caretaker period during which such government changes are still being negotiated. As Bernhard and Leblang (2006: 9) point out, 'markets are also likely to behave differently during unpredictable political processes, not just at their conclusion'.

12. E.g., although the Norwegian Constitution does not specify what a caretaker government can and cannot do (Strøm 1994: 41), the Swedish Constitution does note that caretaker governments, unlike normal governments, cannot dissolve the parliament (Larsson 1994: 172).

13. Further complicating matters, some caretaker governments are put in place precisely to implement significant policy changes before they step down. For instance, the ruling Bulgarian Socialist Party (BSP) was replaced by a caretaker government with Stefan Sofiyanski as prime minister in February 1997 (with new elections to be a couple of months later). Notably, this caretaker government was expected to implement important economic reforms, and had been put in place precisely to do this, ' $\mathrm{g}$ ] iven that the BSP had led the economy to a near meltdown' (Roberts 2008: 537, n.3).

\section{References}

Adcock, R. \& Collier, D. (2001). Measurement validity: A shared standard for qualitiative and quantitative research. American Political Science Review 95: 529-546.

Banks, A.C., Muller, T.C. \& Overstreet, W.R. (eds) (2006). Political handbook of the world, 2005-2006. Washington, DC: Congressional Quarterly Press.

Bernhard, W. \& Leblang, D. (2002). Democratic processes and political risk: Evidence from foreign exchange markets. American Journal of Political Science 46: 316-333.

Bernhard, W. \& Leblang, D. (2006). Pricing politics: Democratic processes and financial markets. New York: Cambridge University Press.

Browne, E.C., Gleiber, D.W. \& Mashoba, C. (1984). Evaluating conflict of interest theory: Western European cabinet coalitions, 1945-1980. British Journal of Political Science 14: $1-32$.

Budge, I. \& Keman, H. (1990). Parties and democracy: Coalition formation and government functioning in twenty states. New York: Oxford University Press.

Diermeier, D. \& Roozendaal, P. van. (1998). The duration of cabinet formation processes in Western multi-party democracies. British Journal of Political Science 28: 609-626.

Druckman, J.N. \& Roberts, A. (2005). Context and coalition-bargaining: Comparing portfolio allocation in Eastern and Western Europe. Party Politics 11: 535-555. 
Herman, V. \& Pope, J. (1973). Minority governments in Western democracies. British Journal of Political Science 3: 191-212.

Ikstens, J. (2008). Latvia. European Journal of Political Research 48(7-8): 1012-1018.

King, G. et al. (1990). A unified model of cabinet dissolution in parliamentary democracies. American Journal of Political Science 34: 846-871.

Krupavicius, A. (2007). Lithuania. European Journal of Political Research 46(7-8): 10191031.

Larsson, T. (1994). Cabinet ministers and parliamentarty government in Sweden'. In M. Laver \& K. Shepsle (eds), Cabinet Minsters and Parliamentary Government. Cambridge: Cambridge University Press.

Laver, M. \& Shepsle K. (1994). Cabinet government in theoretical perspective. In Cabinet ministers and parliamentary government. Cambridge: Cambridge University Press.

Leblang, D. \& Mukherjee, B. (2005). Elections, partisanship and stock market performance: Theory and evidence from a century of American and British returns. American Journal of Political Science 49: 780-802.

Linek, L. (2006). Czech Republic. European Journal of Political Research 45(7-8): 10781083.

Malová, D. \& Učeň, P. (2007). Slovakia. European Journal of Political Research 46(7-8): 1096-1106.

Martin, L.W. \& Vanberg, G. (2003). Wasting time? The impact of ideology and size on delay in coalition formation. British Journal of Political Science 33: 323-344.

Mershon, C. (2002). The costs of coalition. Stanford, CA: Stanford University Press.

Müller-Rommel, F., Fettelschoss, K. \& Harfst, P. (2004). Party government in Central European democracies: A data collection (1990-2003). European Journal of Political Research 43: 869-893.

Müller, W.C. \& Strøm, K. (2000a). Coalition governance in Western Europe: An introduction. In Coalition Governments in Western Europe. Oxford: Oxford University Press.

Müller, W.C. \& Strøm, K. (eds) (2000b). Coalition governments in Western Europe. Oxford: Oxford University Press.

Pettai, V. (2008). Estonia. European Journal of Political Research 46(7-8): 943-948.

Roberts, A. (2008). Hyperaccountability: Economic voting in Central and Eastern Europe. Electoral Studies 27: 553-546.

Somer-Topcu, Z. \& Williams, L. (2008). Survival of the fittest? Cabinet duration in postcommunist Europe. Comparative Politics 40: 313-329.

Spirova, M. (2008). Bulgaria. European Journal of Political Research 47(7-8): 929-934.

Stan, L. \& Zaharia, R. (2008). Romania. European Journal of Political Research 47(7-8): $1115-1126$.

Strøm, K. (1990). Minority governments and majority rule. Cambridge: Cambridge University Press.

Strøm, K. (1994). The role of Norwegian cabinet ministers. In M. Laver \& K. Shepsle (eds), Cabinet ministers and parliamentary government. New York: Cambridge University Press.

Strøm, K., Müller, W.C. \& Bergman, T. (eds) (2003). Delegation and accountability in parliamentary democracies. Oxford: Oxford University Press.

Warwick, P.V. (1996). Coalition government membership in Western European parliamentary democracies. British Journal of Political Science 26: 471-499. 
Woldendorp, J., Keman, H. \& Budge, I. (1993). Handbook of democratic government. Dordrecht: Kluwer Academic Press.

Woldendorp, J., Keman, H. \& Budge, I. (1998). Party government in 20 democracies: An update (1990-1995). European Journal of Political Research 33: 125-164.

Woldendorp, J., Keman, H. \& Budge, I. (2000). Party government in 48 democracies: An update (1945-1998). London: Kluwer Academic Press.

Address for correspondence: Sona N. Golder, Department of Political Science, Florida State University, 553 Bellamy, Tallahassee, FL 32309, USA. E-mail: sgolder@fsu.edu; Homepage: http://polisci.fsu.edu/people/faculty/sgolder.htm. 